\title{
Type I collagen influence on gene expression in UMR106-06 osteoblast-like cells is inhibited by genistein
}

\author{
S Celic ${ }^{1}$, Y Katayama ${ }^{1}$, P J Chilco ${ }^{2}$, T J Martin ${ }^{1}$ and \\ D M Findlay ${ }^{1,3}$
}

${ }^{1}$ St Vincent's Institute of Medical Research, 41 Victoria Parade, Fitzroy 3065, Victoria, Australia, ${ }^{2}$ Department of Medicine, Royal Melbourne Hospital, Royal Parade, Parkville 3052, Victoria, Australia and ${ }^{3}$ Department of Orthopaedics and Trauma, University of Adelaide, Royal Adelaide Hospital, North Terrace, Adelaide 5000, South Australia, Australia

(Requests for offprints should be addressed to D M Findlay, Department of Orthopaedics and Trauma, University of Adelaide, Level 4, Bice Building, Royal Adelaide Hospital, North Terrace, Adelaide 5000, South Australia, Australia)

\begin{abstract}
We have previously shown that an exogenous type I collagen matrix can regulate expression of mRNA for parathyroid hormone (PTH)-related protein $(\mathrm{PTHrP})$ and its receptor, the PTH/PTHrP receptor, in the UMR10606 osteogenic sarcoma cell line, which is considered to be representative of a relatively mature osteoblast phenotype. Consistent with those data, we show here that growth of UMR106-06 cells on type I collagen increased PTH/ PTHrP receptor-binding capacity. Analysis of the binding data showed that the number of PTH/PTHrP receptors expressed by cells cultured on collagen was at least 2 -fold greater than that of cells cultured on plastic.

Expression of mRNA encoding alkaline phosphatase (ALP) and osteopontin (OP) was also upregulated in cells cultured on collagen, suggesting that interaction with collagen promotes the osteoblast phenotype in this cell line. Retinoic acid (RA), which has also been shown to promote osteoblastic differentiation, synergized with type I collagen to cause super-induction of OP mRNA. In contrast, RA abolished the collagen-induced increase in ALP mRNA and PTH/PTHrP receptor mRNA. The collagen-mediated increase in the expression of $\mathrm{OP}$ and
\end{abstract}

PTH/PTHrP receptor mRNA, but not that of ALP, was perturbed by prior covalent modification of the collagen by non-enzymatic glycation. The collagen effects did not occur via interaction with RGD amino acid domains in type I collagen, but evidence was obtained for involvement of the DGEA amino acid cell-binding domain.

The mechanism by which plating of UMR106-06 cells on a type I collagen substrate affects $\mathrm{PTH} / \mathrm{PTHrP}$ receptor mRNA levels was investigated. Inhibition of cytoskeletal organization using cytochalasin $\mathrm{D}$, and inhibitors of protein phosphatases, protein kinase $\mathrm{C}$, phospholipase $\mathrm{C}$ and cyclooxygenase, did not abrogate the collagen-mediated effects. In contrast, treatment of cells with the protein tyrosine kinase inhibitor genistein, but not herbimycin A, dose-dependently abolished the collagen effects on the expression of PTH/PTHrP receptor, ALP and OP mRNA. These results show that a type I collagen substrate influences the expression of osteoblast-associated genes in a cell model of mature osteoblasts and suggests that this involves, at least in part, changes in intracellular tyrosine phosphorylation.

Journal of Endocrinology (1998) 158, 377-388

\section{Introduction}

The importance of cell adhesion for normal cell function has now been well demonstrated in a number of systems (Adams \& Watt 1993). In bone, where the extracellular matrix (ECM) comprises approximately $85 \%$ type I collagen (Eyer 1980), cellular interaction with matrix components has been shown to be important in both osteoclastic activity (Shankar et al. 1993) and regulation of the osteoblast phenotype (Andrianarivo et al. 1992, Traianedes et al. 1993). For example, we have previously shown that plating of preosteoblastic cells on type I collagen promotes osteoblastic differentiation (Traianedes et al. 1993). More recently, we have shown in a model of the mature osteoblast, UMR106-06 cells, that a type I collagen substrate increases the expression of mRNA for the parathyroid hormone (PTH)-related protein $(\mathrm{PTHrP})$ and its receptor, the $\mathrm{PTH} / \mathrm{PTHrP}$ receptor (Celic et al. 1996) as well as the response of cells to PTH stimulation, reflected by changes in PTH-induced cAMP accumulation (Celic et al. 1996). This result was consistent with the demonstrated increase in expression of this receptor as a function of osteoblast maturation (Suda et al. 1995, Bos et al. 1996).

The mechanism(s) by which ECM molecules regulate gene expression is not well understood, although a number of well characterized cell surface adhesion molecules are clearly involved (Hynes 1992). In particular, members of 
the integrin family of receptors have been shown to mediate many of the effects of collagen, fibronectin and other ECM molecules. Upon activation of these receptors by ECM ligand binding, receptor clustering occurs and the formation of focal adhesions (Turner \& Burridge 1991). This aggregation of receptors leads to a number of intracellular responses such as the alteration of intracellular $\mathrm{pH}$, calcium levels, protein phosphorylation states, generation of arachidonic acid metabolites and re-arrangement of the cytoskeleton (Hynes 1992). Integrin-mediated regulation of gene expression appears to involve modulation of several protein kinases, including tyrosine kinases, although these events are clearly cell specific (Kornberg et al. 1991, Schwartz et al. 1995).

The present study was designed to extend our earlier observations on matrix modulation of the $\mathrm{PTH} / \mathrm{PTHrP}$ receptor mRNA in UMR106-06 cells (Celic et al. 1996). Using ligand-binding studies, we have shown that culture of UMR106-06 cells on a type I collagen substrate upregulates the cell surface expression of the $\mathrm{PTH} / \mathrm{PTHrP}$ receptor, which is antagonized by retinoic acid (RA) treatment. Growth of these cells on collagen produced changes in the expression of alkaline phosphatase (ALP) and osteopontin (OP) mRNA, as seen previously in the preosteoblastic cell line, UMR201 (Traianedes et al. 1993). Experiments were performed to elucidate the intracellular and extracellular mechanisms by which collagen exerted these effects, the latter using approaches aimed at perturbing the presumed basis of these effects, the collagen-integrin receptor interaction. The results suggest that a direct interaction between UMR106-06 cells and the collagen proteins produced the collagen-mediated effects on osteoblastic gene expression, by a mechanism that is likely to involve protein tyrosine kinase activity.

\section{Materials and Methods}

\section{Cell culture}

The rat osteosarcoma osteoblast-like cell line UMR106-06 (Forrest et al. 1985) was cultured in Eagle's minimum essential medium (MEM; Gibco Laboratories, Grand Island, NY, USA) containing 10\% foetal bovine serum (Cytosystems, Castle Hill, NSW, Australia). All media contained gentamicin $(80 \mathrm{mg} / \mathrm{l}$; DBL, Mulgrave, Victoria, Australia), minocycline $(1 \mathrm{mg} / \mathrm{ml}$; Sigma Chemical Co., St Louis, MO, USA) and Hepes (16 mM; Gibco Laboratories). Cells were incubated at $37^{\circ} \mathrm{C}$ and equilibrated with $5 \% \mathrm{CO}_{2}$ in humidified air. Cells were used between passages 10 and 30. Trypsin-EDTA was used for harvesting cells on plastic.

\section{Type I collagen gels}

Cells were grown directly on plastic cell culture dishes or on a thin layer of gelled rat tail type I collagen
(Collaborative Research, Waltham, MA, USA). The collagen was diluted in MEM to a stock concentration which would result in a gel of $25 \mu \mathrm{g} / \mathrm{cm}^{2}$ when $1 \mathrm{ml}$ was used to coat $58 \mathrm{~cm}^{2}$ petri dishes, for RNA harvests, or $200 \mu \mathrm{l}$ for $3.8 \mathrm{~cm}^{2}$ wells, for binding experiments. The collagen gels were allowed to set at room temperature prior to incubation at $37^{\circ} \mathrm{C}$ overnight. Glycation of collagen (AGE collagen) was achieved by incubating unmodified collagen gels of $50 \mu \mathrm{g} / \mathrm{cm}^{2}$ with $0.5 \mathrm{M}$ glucose-6-phosphate for 0,1 or 3 weeks to generate collagen substrates with increasing glycation levels, as previously described (Katayama et al. 1996). AGE modification of collagen was quantified by measuring AGEspecific fluorescence emission spectra at $370 \mathrm{~nm}$ excitation wavelength and $440 \mathrm{~nm}$ emission wavelength, using a fluorimeter (F-850, Hitachi Industrial Co. Ltd, Tokyo, Japan). Collagen-coated dishes after 0,1 or 3 weeks glycation contained $0,16 \cdot 2$ and $31 \cdot 2$ relative fluorescence units/mg protein respectively. Cells were cultured onto plastic, control unmodified collagen $\left(50 \mu \mathrm{g} / \mathrm{cm}^{2}\right.$ for AGE collagen experiments) or AGE collagen, for $24 \mathrm{~h}$ prior to total RNA harvest for analysis by Northern blot or cell harvest for counting. Prior to RNA harvest or cell counting, collagen gels were dissolved using $1 \mathrm{mg} / \mathrm{ml}$ collagenase (Worthington Biochemical Corp., Freehold, NJ, USA) in PBS at $37^{\circ} \mathrm{C}$ for $20 \mathrm{~min}$.

\section{Inhibitors and peptides}

Cells were subcultured onto plastic or a $25 \mu \mathrm{g} / \mathrm{cm}^{2}$ type I collagen gel, in $58 \mathrm{~cm}^{2}$ dishes in the presence or absence of inhibitors or activators of signal transduction pathways or peptides that mimic putative cell-binding domains in collagen. After $24 \mathrm{~h}$ incubation, total RNA was harvested and analysed by Northern blot. Substances were: herbimycin A, genistein (4',5,7-trihydroxyisoflavone), chelrythrine chloride, calphostin C, microcystin-LR, H-7, U-73122, tautomycin, calyculin A, okadaic acid (potassium salt) and phorbol 12-myristate 13-acetate (PMA), thapsigargin and indomethacin (purchased from BIOMOL Research Laboratories, Plymouth Meeting, PA, USA), sodium metavanadate (Sigma Chemical Co.). GRGDTP and GRGESP peptides were purchased from Life Technologies Pty Ltd (Grand Island, NY, USA) and DGEA and KDGE peptides were custom synthesized from Auspep Pty Ltd (Parkville, Australia).

\section{Northern blot analysis}

Total cellular RNA was extracted from cells in $58 \mathrm{~cm}^{2}$ petri dishes using guanidinium thiocyanate (Chomczynski \& Sacchi 1987). Twenty micrograms of each sample of RNA were electrophoresed through a 1.2\% (w/v) formaldehyde gel and transferred to nylon filter (Hybond $\mathrm{N}+$, Amersham International, Amersham, Bucks, UK or Magna nylon transfer membrane, Micron Separations Inc., 
Westboro, MA, USA) (Sambrook et al. 1989). Filters were hybridized with ${ }^{32} \mathrm{P}-\mathrm{dATP}$ labelled (by random priming) fragments: R15b fragment of rat $\mathrm{PTH} / \mathrm{PTHrP}$ receptor cDNA (Abou-Samra et al. 1992), rat OP (Yoon et al. 1987), rat ALP (Noda \& Rodan 1987) or, for loading standardization, human liver glyceraldehyde-3-phosphate (GAPDH) cDNA (Arcari et al. 1984). The filters were exposed to a phosphor screen and the signal quantified using a PhosphorImager SF (Molecular Dynamics, Sunnyvale, CA, USA) and the computer analysis program ImageQuant (Molecular Dynamics).

\section{${ }^{125}$ I labelling of PTH}

$\left[\mathrm{Nle}^{8,18}, \mathrm{Tyr}^{34}\right] \mathrm{bPTH}_{(1-34)} \mathrm{NH}_{2}$ (a gift from the Division of Bone and Mineral Metabolism, Beth Israel Deaconess Medical Centre, Boston, MA, USA) was labelled with ${ }^{125} \mathrm{I}$ using IODO-GEN Iodination reagent (Pierce, Rockford, IL, USA), as previously described (Goldman et al. 1988). The reaction mixture was purified using a C18 SepPak column, as described previously (Goldman et al. 1988), and stored at $-20{ }^{\circ} \mathrm{C}$.

\section{Binding studies}

To determine the cell surface expression of the PTH/

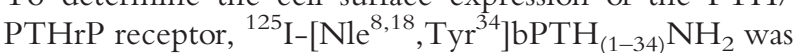
used in binding studies. UMR106-06 cells were subcultured onto plastic or $25 \mu \mathrm{g} / \mathrm{cm}^{2}$ type I collagen gel, in $3.8 \mathrm{~cm}^{2}$ wells, and binding studies were performed on cell monolayers at or near confluence $24 \mathrm{~h}$ later. For binding, growth medium was removed and cells were washed with PBS prior to adding binding media, consisting of MEM, $2 \%(\mathrm{w} / \mathrm{v})$ BSA and $0 \cdot 1 \%(\mathrm{w} / \mathrm{v})$ bacitracin. For association experiments, $0 \cdot 1$ pmol ${ }^{125} \mathrm{I}_{-}\left[\mathrm{Nle}^{8,18}, \mathrm{Tyr}^{34}\right] \mathrm{bP}-$ $\mathrm{TH}_{(1-34)} \mathrm{NH}_{2}$ was added per well in the presence (non-specific binding) or absence (total binding) of $10^{-6} \mathrm{M}$ unlabelled $\mathrm{PTH}_{(1-34)}$. The binding reaction was terminated at various times by aspirating the binding media and washing the cells with cold PBS. For dissociation experiments cells were incubated with $0 \cdot 2 \mathrm{pmol}^{125} \mathrm{I}-$ $\left[\mathrm{Nle}^{8,18}, \mathrm{Tyr}^{34}\right] \mathrm{bPTH}_{(1-34)} \mathrm{NH}_{2}$ for $1 \mathrm{~h}$ to allow steadystate binding. The media were then aspirated and the cells washed with PBS prior to adding fresh binding media with $10^{-6} \mathrm{M}$ unlabelled $\mathrm{PTH}_{(1-34)}$ for various time intervals. In saturation binding experiments, cells, grown in the presence or absence of RA, were incubated with increasing concentrations of ${ }^{125} \mathrm{I}-\left[\mathrm{Nle}{ }^{8,18}, \mathrm{Tyr}^{34}\right] \mathrm{bP}-\mathrm{TH}_{(1-34)} \mathrm{NH}_{2}$, and incubated for $1 \mathrm{~h}$ at room temperature. Cell-bound ${ }^{125} \mathrm{I}-\left[\mathrm{Nle}^{8,18}, \mathrm{Tyr}^{34}\right] \mathrm{bPTH}_{(1-34)} \mathrm{NH}_{2}$ was determined by solubilizing the cells with $0.5 \mathrm{M} \mathrm{NaOH}$ and counting ${ }^{125} \mathrm{I}$ using a $\gamma$-counter. Cell numbers in each experimental group were determined in order to enable expression of all results as picomoles per million cells.

\section{Binding analysis and statistics}

Four saturation binding experiments, each with samples in triplicate, were used for analysis. Binding data were analysed by the iterative curve-fitting program LIGAND (Munson \& Rodbard 1980) as adapted by McPherson (1985). Statistical significance of changes in binding parameters were assessed using a Student's $t$-test, following logarithmic transformation of parameters and $P$ values of $<0.05$ were regarded as significant.

\section{Results}

\section{Effect of collagen on PTH/PTHrP receptor-binding capacity}

We have previously shown that in UMR106-06 cells grown on a type I collagen substrate, $\mathrm{PTH} / \mathrm{PTHrP}$ receptor mRNA levels were increased, and cAMP accumulation in response to PTH was enhanced, compared with cells grown on tissue culture plastic (Celic et al. 1996). Since these results suggested increased cell surface PTH/PTHrP receptor expression, we sought to confirm this by measuring receptor-binding directly. When the $\mathrm{PTH}$ analogue ${ }^{125} \mathrm{I}_{-}\left[\mathrm{Nle}^{8,18}, \mathrm{Tyr}^{34}\right] \mathrm{bPTH}_{(1-34)} \mathrm{NH}_{2}$ was used as radioactive ligand, a marked increase in specific binding was seen in cells cultured on collagen compared with cells grown on plastic, whether experiments were performed at room temperature (Fig. 1), $4{ }^{\circ} \mathrm{C}$ (data not shown), or at $37^{\circ} \mathrm{C}$ (data not shown). The time to steady-state binding of ${ }^{125} \mathrm{I}-\left[\mathrm{Nle}{ }^{8,18}, \mathrm{Tyr}^{34}\right] \mathrm{bP}-\mathrm{TH}_{(1-34)} \mathrm{NH}_{2}$ in cells on plastic or collagen was similar (Fig. 1) with maximal binding reached after approximately $60 \mathrm{~min}$. However, approximately twice as much ${ }^{125} \mathrm{I}-\left[\mathrm{Nle}^{8,18}, \mathrm{Tyr}^{34}\right] \mathrm{bPTH}_{(1-34)} \mathrm{NH}_{2}$ bound specifically to cells cultured on collagen than on plastic (for the experiment shown in Fig. 1, 2.4\% vs 1.3\% of added ligand respectively). The rate of dissociation of bound ${ }^{125} \mathrm{I}-\left[\mathrm{Nle}^{8,18}, \mathrm{Tyr}^{34}\right] \mathrm{bPTH}_{(1-34)} \mathrm{NH}_{2}$ was similar from cells on plastic or collagen (Fig. 1), occurring with a $\mathrm{t}_{1 / 2}$ of approximately $20 \mathrm{~min}$.

Saturation binding studies were performed to determine cell surface receptor number and ligand affinity. Analysis of the binding data indicated that the radioligand bound to a single population of high-affinity binding sites. In cells grown on collagen, PTH/PTHrP receptor number was approximately 2 -fold greater than in cells grown on plastic (Table 1). The increased binding was not due to increased ligand affinity for the receptor site; the dissociation constant for the ligand-receptor interaction was in fact slightly higher with cells grown on collagen than cells grown on plastic. RA treatment of the cells grown on either substrate significantly decreased the number of ligand-binding sites compared with the respective untreated controls.

\section{Collagen effect on $m R N A$ expression of $O P$ and $A L P$}

There is now good evidence that expression of the $\mathrm{PTH} / \mathrm{PTHrP}$ receptor increases as a function of osteoblast 


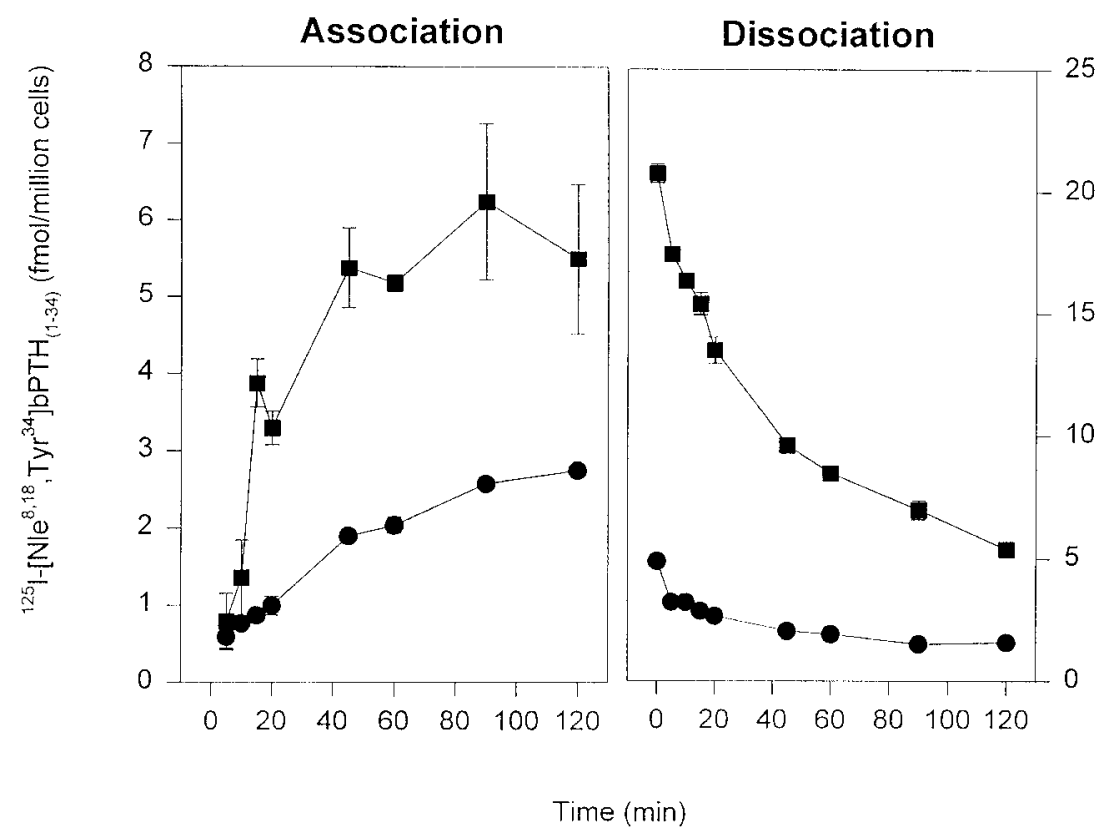

Figure 1 Time course of specific association and dissociation of ${ }^{125} \mathrm{I}-\left[\mathrm{Nle}^{8,18}, \mathrm{Tyr}^{34}\right] \mathrm{bPTH}_{(1-34)} \mathrm{NH}_{2}$ with PTH/PTHrP receptors on UMR106-06 cells. UMR106-06 cells cultured for $24 \mathrm{~h}$ on plastic $(\mathbf{)})$ or type I collagen $(\boldsymbol{\square})$ were incubated at room temperature with ${ }^{125}$-labelled ligand for the times indicated. Dissociation of bound ligand was measured as described in the Materials and Methods. Specific binding values were obtained by subtracting binding in the presence of $10^{-6} \mathrm{M}$ unlabelled $\mathrm{PTH}_{(1-34)}$ from total binding. Results are expressed as binding per $10^{6}$ cells, where each point represents the mean \pm S.E.M. of triplicate wells from a representative experiment. This experiment was repeated twice with similar results.

differentiation (McCauley et al. 1995, Suda et al. 1995, Bos et al. 1996). We therefore examined the expression of two other osteoblast-associated gene products, OP and ALP, in response to culturing of UMR106-06 cells on collagen. It was observed that growing the cells on collagen for $24 \mathrm{~h}$ increased the steady-state levels of both OP mRNA and ALP mRNA approximately 2 -fold, compared with cells grown on plastic (Fig. 2). Treatment with RA had an effect on the expression of ALP mRNA (Fig. 2B) similar to that on $\mathrm{PTH} / \mathrm{PTHrP}$ receptor mRNA, decreasing mRNA levels on both substrates and abrogating the effect of collagen. However, RA treatment increased the expression of OP mRNA on plastic approximately 2 -fold and synergized with collagen to cause superinduction of approximately 8-fold, compared with control cells on plastic (Fig. 2C). The time course of these events was studied and these results are shown in Fig. 3. The temporal effects of collagen were different for the three mRNA species. In addition, RA treatment enhanced, in the case of OP mRNA, or inhibited, in the case of ALP and $\mathrm{PTH} / \mathrm{PTHrP}$ receptor mRNA, the effects of collagen at each of the times studied.

Table 1 PTH/PTHrP receptor binding site numbers and affinities for UMR106-06 cells cultured on plastic or type I collagen with or without RA treatment. Values shown are \pm S.E.M.

\begin{tabular}{|c|c|c|c|}
\hline & $\begin{array}{l}B_{\max }\left(\times 1^{-11}\right) \\
(M)\end{array}$ & $\begin{array}{l}\text { Receptor } \\
\text { number/cell }\end{array}$ & $\begin{array}{l}K_{\mathbf{d}}\left(\times 10^{-\mathbf{9}}\right) \\
\left(\mathrm{M}^{-1}\right)\end{array}$ \\
\hline Plastic & $3 \cdot 30 \pm 0 \cdot 43$ & $9900 \pm 1290$ & $1 \cdot 13 \pm 0 \cdot 16$ \\
\hline Plastic+RA & $0.59 \pm 0.37^{a}$ & $1768 \pm 111^{a}$ & $0 \cdot 61 \pm 0 \cdot 40$ \\
\hline Collagen & $7 \cdot 97 \pm 1 \cdot 08^{a}$ & $23915 \pm 3230^{a}$ & $1 \cdot 95 \pm 0 \cdot 29$ \\
\hline Collagen + RA & $0 \cdot 46 \pm 0 \cdot 32^{b}$ & $1379 \pm 963^{b}$ & $0 \cdot 35 \pm 0 \cdot 25^{t}$ \\
\hline
\end{tabular}




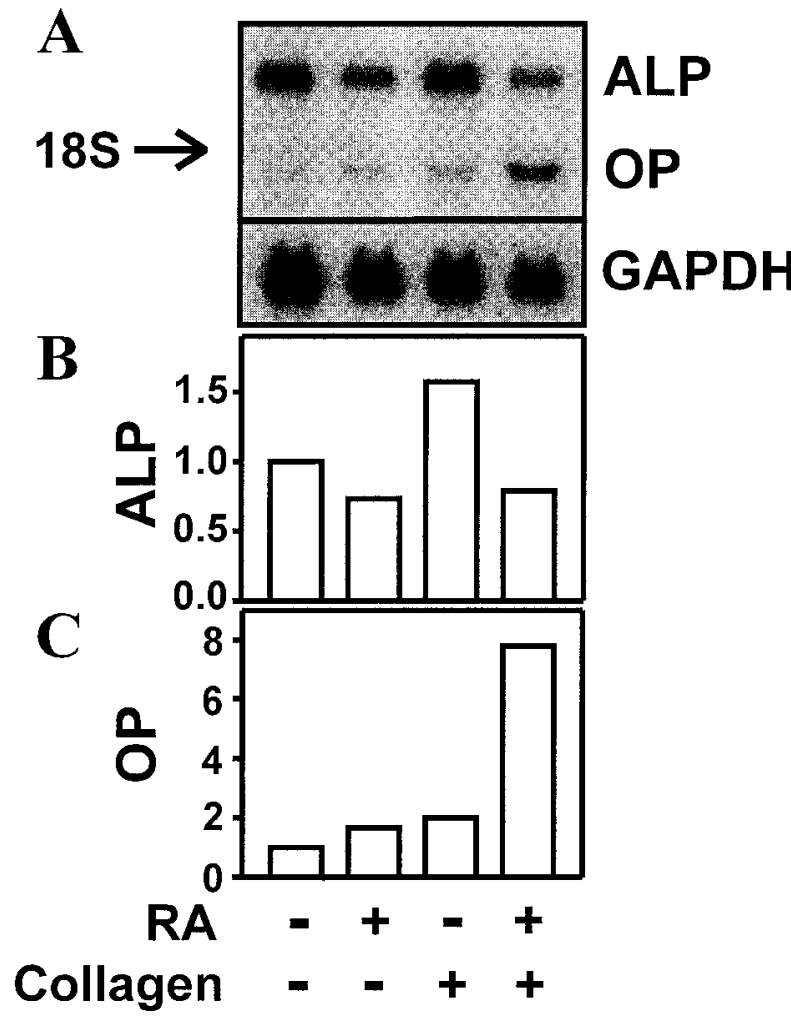

Figure 2 Effect of plating UMR106-06 cells on a type I collagen substrate on the expression of OP and ALP mRNA. Cells were plated onto plastic or a type I collagen gel in the presence or absence of $10^{-6} \mathrm{M}$ RA, for $24 \mathrm{~h}$ prior to extraction of total RNA. Signals on Northern blots corresponding to the respective mRNA species are shown in (A). Samples were normalized for mRNA content with reference to the housekeeping gene GAPDH. Generated signals were quantified using phosphorimaging analysis and are expressed as the ratio of ALP (B) or OP (C) mRNA to GAPDH mRNA, where the result for untreated cells on plastic was given the value of 1 . This experiment is representative of three similar experiments.

\section{Investigation of cellular interaction with collagen}

Experiments were designed to investigate the nature and importance of cellular interaction with type I collagen for the collagen-induced effects described above. First, we tested the effect of covalent modification of type I collagen by non-enzymatic glycation. Culture of UMR106-06 cells on AGE collagen reduced or abolished the increase in PTH/PTHrP receptor mRNA (Fig. 4D) and OP mRNA (Fig. 4C) levels seen in cells on unmodified type I collagen. However, ALP mRNA expression, which is also increased in cells cultured on control collagen, remained increased when cells were cultured on AGE collagen at several levels of glycation (Fig. 4B). The ability of the cells to adhere to AGE collagen was not different from unmodified collagen.

Secondly, cells were plated onto collagen in the presence of peptides that represent putative cell-binding
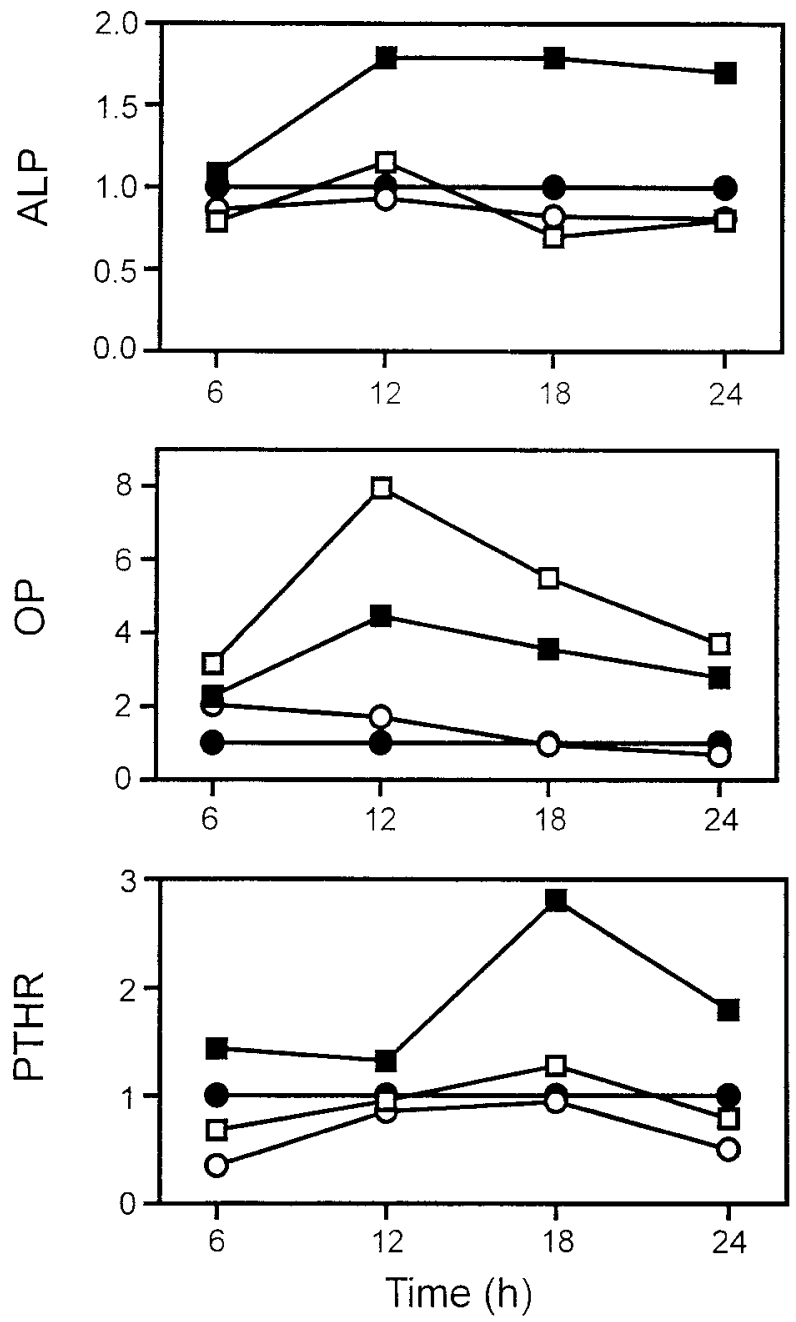

Figure 3 Time course of ALP, OP and PTH/PTHrP receptor (PTHR) mRNA expression in UMR106-06 cells grown on plastic or type I collagen. Cells were cultured on plastic $(O, \mathbf{0})$ or type I collagen $(\square, \mathbf{\square})$ in the presence $(\bigcirc, \square)$ or absence $(\mathbf{0}, \mathbf{\square})$ of $10^{-6} \mathrm{M} \mathrm{RA}$, as described in Materials and Methods, for 6, 12, 18 or $24 \mathrm{~h}$ prior to extraction of total RNA. Signals on Northern blots corresponding to ALP, OP and PTH/PTHrP receptor mRNA species were quantified and normalized for mRNA content with reference to GAPDH mRNA levels. Data obtained were re-arranged to emphasize the level of expression of these markers over a $24 \mathrm{~h}$ period in the different experimental groups, compared with untreated cells cultured on plastic, for which results at $6 \mathrm{~h}$ were given the arbitrary value of 1 . This experiment is representative of three similar experiments.

domains in collagen. The peptide GRGDTP was used to determine whether attachment at the RGD amino acids site in collagen might mediate the collagen-induced effects in UMR106-06 osteoblast-like cells. The peptide GR GESP was used as a negative control. Peptide concentrations ranging from $0 \cdot 01 \mu \mathrm{M}$ to $1 \cdot 0 \mathrm{mM}$ did not alter cell attachment (not shown) or mRNA steady-state levels of the PTH/PTHrP receptor, OP and ALP in cells cultured 
A

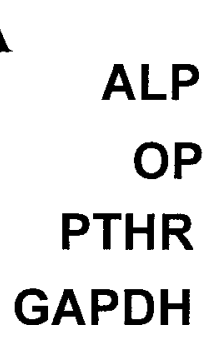

B

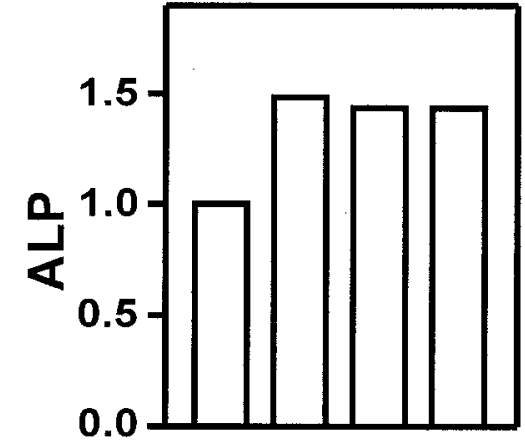

C

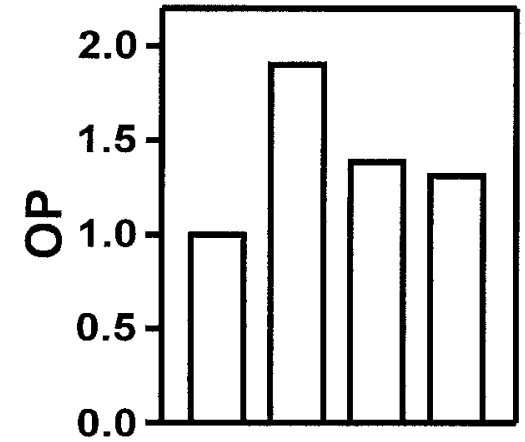

D

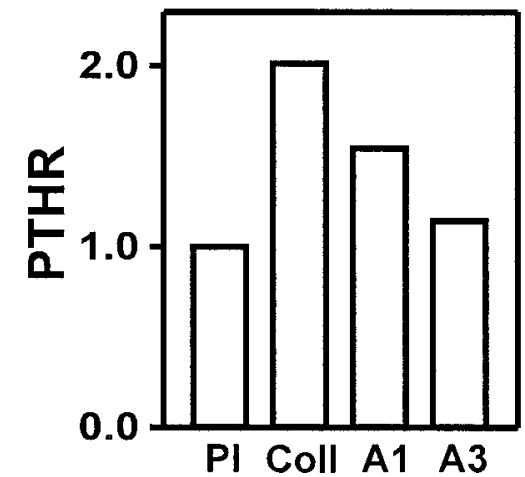

Figure 4 Effect of culturing UMR106-06 cells on AGE collagen compared with culture on plastic or unmodified type I collagen. Cells were cultured for $24 \mathrm{~h}$ on plastic $(\mathrm{Pl})$, unmodified type I collagen (Coll) or AGE collagen with varying degrees of glycation (A1, A3: 1 or 3 weeks of glycation respectively). Shown is a Northern blot $(A)$ with signals corresponding to mRNA for the PTH/PTHrP receptor (PTHR), OP, ALP and the housekeeping gene used for normalization,

GAPDH. Signals were quantified using phosphorimager analysis and values are expressed as the ratio of ALP (B), OP (C) or PTH/PTHrP receptor (D) to GAPDH mRNA levels, where the result for untreated cells on plastic was given the value of 1 . This experiment is representative of two similar experiments.

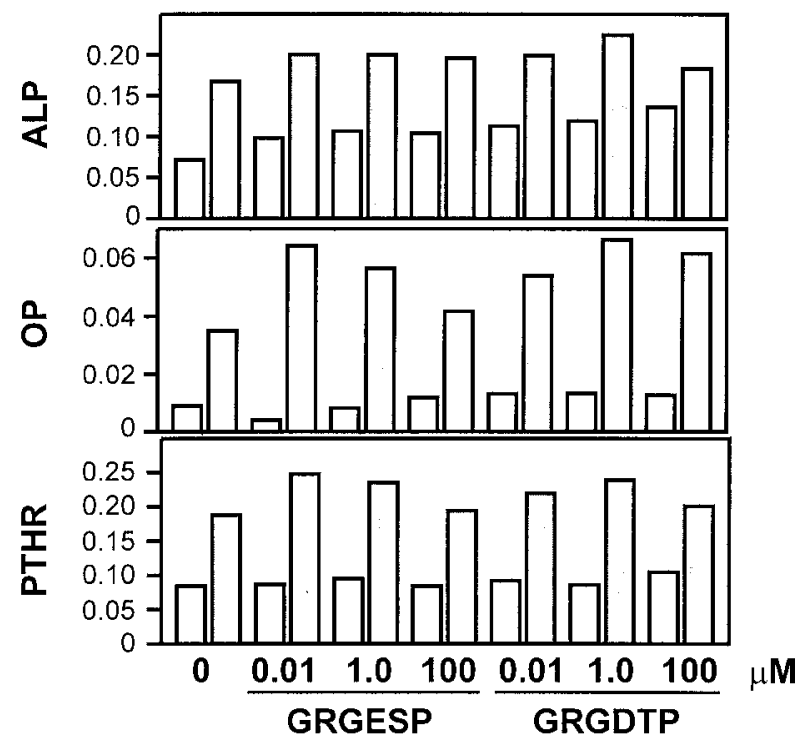

Figure 5 Effect of GRGDTP and GRGESP peptide on collagenmediated changes in gene expression. UMR106-06 cells were incubated with GRGDTP peptide, or GRGESP peptide, at concentrations of $0 \cdot 01,1 \cdot 0$ or $100 \mu \mathrm{M}$, for 15 min prior to plating at $90 \%$ confluency onto uncoated dishes (unfilled bars) or dishes coated with $25 \mu \mathrm{g} / \mathrm{cm}^{2}$ type I collagen (shaded bars), for $24 \mathrm{~h}$ prior to total RNA harvest. ALP, OP, PTH/PTHrP receptor (PTHR) and GAPDH mRNA expression were quantified by Northern blot analysis and the signals generated were quantified using phosphorimaging technology. The levels of each of the mRNA species are expressed as a ratio of GAPDH mRNA. This experiment is representative of three similar experiments.

on either plastic or collagen (shown for $0 \cdot 01$ to $100 \mu \mathrm{M}$, Fig. 5).

To investigate a potential role for the DGEA amino acids site of the collagen molecule, experiments were designed based on the work described by Staatz et al. (1991), in which the DGEA peptide substantially inhibited platelet adhesion to collagen, with the KDGE peptide serving as a negative control. Incubation of UMR106-06 cells on collagen in the presence of $5 \mathrm{mM}$ DGEA peptide inhibited cell spreading (Fig. 6D), compared with untreated cells on collagen (Fig. 6B). In contrast, DGEA peptide had little effect on cell spreading with cells cultured on plastic (Fig. 6C) compared with the untreated control (Fig. 6A). The negative control peptide, KDGE, had no effect on cell spreading on plastic or collagen (Fig. 6E and F respectively). The effect of these peptides on ALP, OP and the PTH/PTHrP receptor mRNA expression was mRNA-species dependent. The $5 \mathrm{mM}$ DGEA peptide eliminated the collagen-mediated increase in ALP and PTH/PTHrP receptor mRNA expression in cells cultured on plastic or collagen (Fig. 7), although the KDGE peptide had similar activity. Both DGEA and KDGE peptides $(5 \mathrm{mM})$ increased the expression of OP mRNA in cells cultured on collagen but not plastic, compared with untreated controls (Fig. 7). 

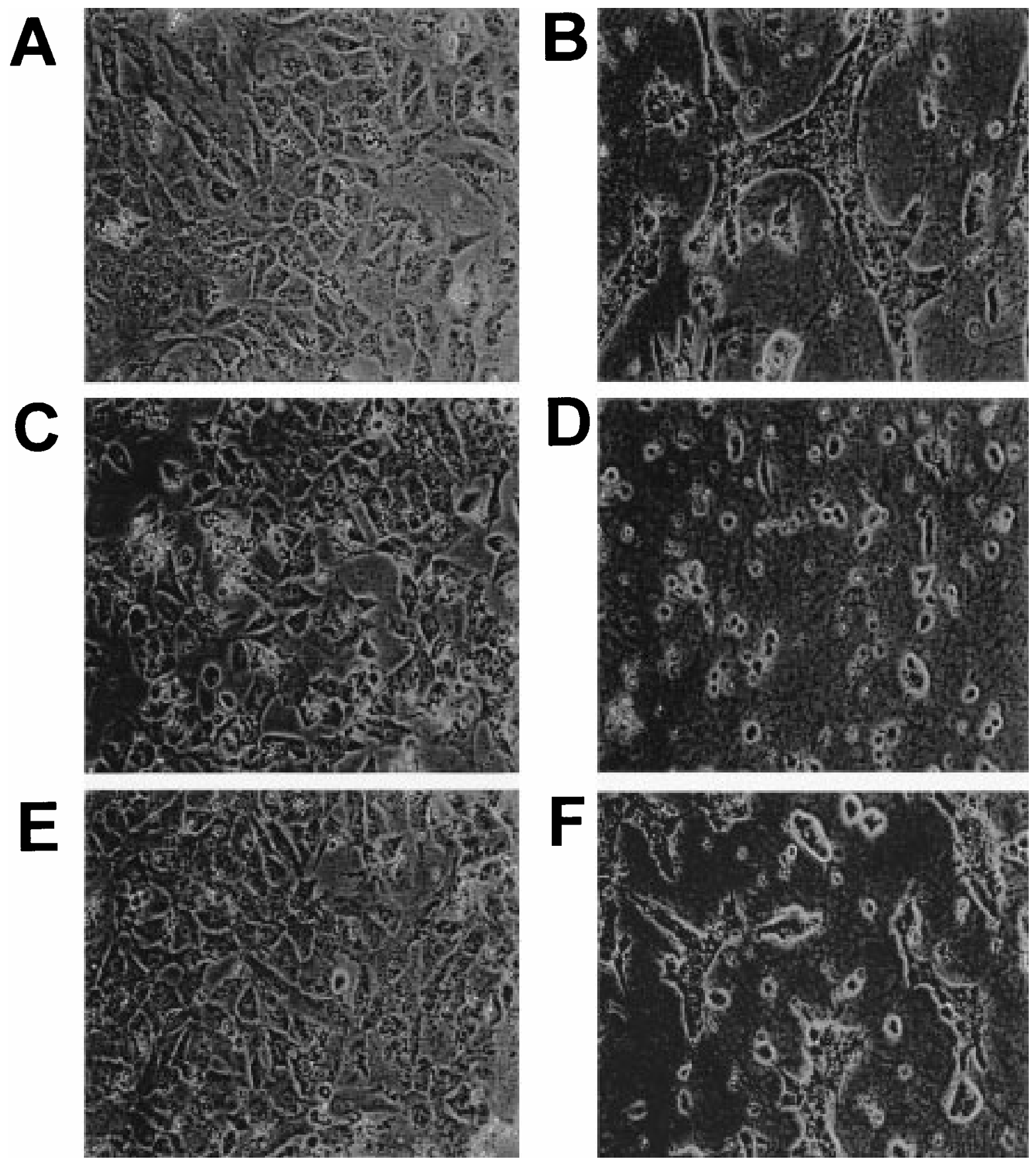

Figure 6 Effect of DGEA and KDGE peptide on UMR106-06 cell morphology. Cell suspensions were incubated with 5 mM DGEA peptide $(C, D)$, negative control peptide, $K D G E,(E, F)$ or no peptide $(A, B)$ for 15 min prior to plating at $90 \%$ confluency onto uncoated dishes (A, C, E) or dishes coated with $25 \mu \mathrm{g} / \mathrm{cm}^{2}$ type I collagen (B, D, F). The cells were incubated for $22 \mathrm{~h}$. Magnification, $\times 66$.

Investigation of intracellular signalling pathways

To investigate the mechanism of the collagen-induced effects in UMR106-06 cells, we used inhibitors or acti- vators of various intracellular signalling pathways. These were: cytochalasin $\mathrm{D}$, an inhibitor of actin filament rearrangement; the phorbol ester, PMA, which activates, and chelerythrine chloride, calphostin $\mathrm{C}$ and $\mathrm{H} 7$, which 

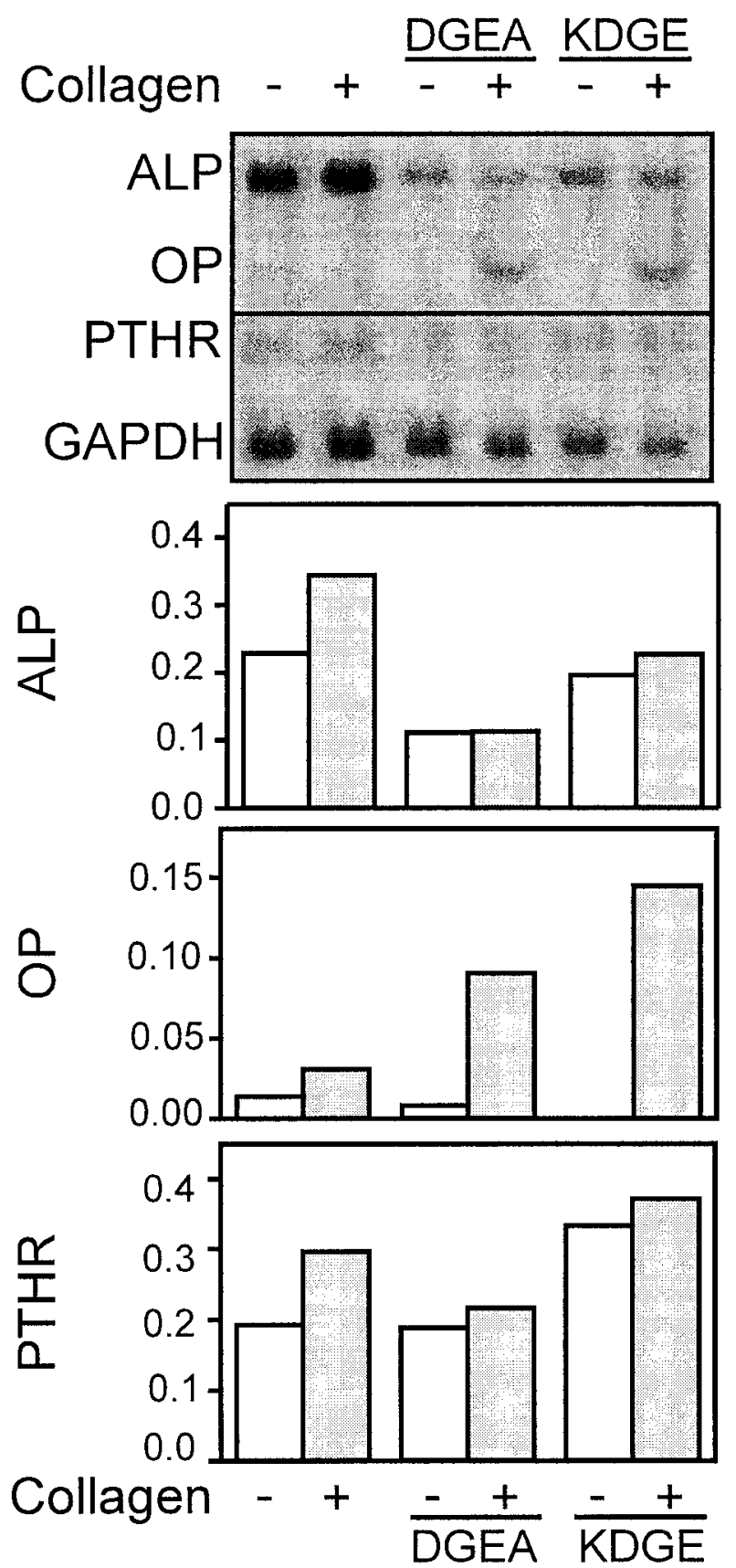

Figure 7 Effect of DGEA and KDGE peptide on collagenmediated changes in gene expression. UMR106-06 cell suspensions were incubated with DGEA or KDGE peptides, at $5 \mathrm{mM}$, for $15 \mathrm{~min}$ prior to plating at $90 \%$ confluency onto uncoated dishes $(-)$ or dishes coated with $25 \mu \mathrm{g} / \mathrm{cm}^{2}$ type I collagen (+). RNA was harvested $24 \mathrm{~h}$ later. ALP, OP, PTH/PTHrP receptor (PTHR) and GAPDH mRNA levels were quantified by Northern blot analysis. The signals generated were quantified using phosphorimaging technology. The expression levels of each of the mRNA species are expressed as a ratio of GAPDH mRNA levels. This experiment is representative of three similar experiments.

inhibit, protein kinase $\mathrm{C}$; okadaic acid, calyculin $\mathrm{A}$ and microcystin LR, which inhibit serine/threonine protein phosphatases and sodium metavanadate, which inhibits protein tyrosine phosphatases; herbimycin A and genistein, which inhibit protein tyrosine kinases; thapsigargin, which interferes with intracellular calcium storage; U73122, which inhibits phospholipase C; and indomethacin, which inhibits cyclooxygenase, as listed in Table 2 . To identify pathways differentially activated by growth of cells on collagen, it was of interest to find an agent which would specifically inhibit the collagen-mediated effects on mRNA levels in UMR106-06 cells. Several agents were found to increase or decrease expression of the PTH/ PTHrP receptor mRNA, but, with the exception of genistein and one concentration of sodium metavanadate, they did so in cells on both plastic and collagen, as summarized in Table 2.

The protein tyrosine kinase inhibitor, genistein, but not herbimycin A, differentially decreased the collagenmediated increase in expression of mRNA for PTH/ PTHrP receptor, ALP and OP. Although high concentrations of genistein decreased mRNA expression in cells cultured on plastic as well as collagen, lower concentrations, that did not affect expression in cells cultured on plastic, were observed to dose-dependently inhibit the collagen-mediated increase (Fig. 8). Since genistein differentially affected $\mathrm{PTH} / \mathrm{PTH}$ receptor mRNA levels in cells on collagen, we examined also ALP and OP mRNA levels in genistein-treated cells. Collagen induction of these mRNA species was also inhibited by genistein (Fig. 8).

\section{Discussion}

The ECM, in addition to its structural role, interacts with cells to provide important signals for differentiated function. Relevant to the present work is the demonstrated ability of the ECM to alter also cellular responses of osteoblasts to soluble agonists, specifically the hormone PTH. Using an osteoblast-like osteosarcoma cell line, UMR106-06 cells, we have shown here that the increased responsiveness of these cells to $\mathrm{PTH}$ stimulation is due to an increase in the number of cell surface PTH/PTHrP receptors. The magnitude of increase in receptor number was in close agreement with the observed changes in mRNA levels for this receptor and in the cAMP levels accumulated in response to PTH stimulation (Celic et al. 1996). RA treatment decreased the number of receptors expressed by the cells cultured on either substrate, also consistent with previous findings of decreased receptor mRNA levels and cAMP levels in response to PTH stimulation in RA-treated cells (Celic et al. 1996).

There are a number of reports suggesting that culture of cells on the appropriate physiological ECM results in a more differentiated cell phenotype (Blum et al. 1987, Andrianarivo et al. 1992, Lynch et al. 1995). Our finding 
Table 2 Effect of various agents, which affect intracellular signalling, on the expression of PTH/PTHrP receptor mRNA in UMR106-06 cells grown on collagen or plastic. Cells were plated onto uncoated dishes (plastic), or dishes coated with collagen, in the absence or presence of the indicated concentrations of listed agents. After $24 \mathrm{~h}$, cells were examined microscopically for inhibition of cell attachment prior to isolating total RNA and performing Northern blot analysis. PTH/PTHrP receptor mRNA levels were normalized with respect to GAPDH mRNA levels. The data are representative of at least two experiments with each agent

\begin{tabular}{|c|c|c|c|c|c|c|}
\hline & \multirow[b]{3}{*}{ Agent } & \multirow{3}{*}{$\begin{array}{l}\text { Concentration } \\
\text { (M) }\end{array}$} & \multicolumn{4}{|c|}{ Effect on } \\
\hline & & & \multicolumn{2}{|c|}{ Cell attachment } & \multicolumn{2}{|c|}{$\begin{array}{l}\text { PTH/PTHrP receptor } \\
\text { mRNA expression }\end{array}$} \\
\hline & & & Plastic & Collagen & Plastic & Collagen \\
\hline \multicolumn{7}{|l|}{ Action } \\
\hline \multirow[t]{6}{*}{ Protein kinase $\mathrm{C}$ inhibition } & Chelerythrine chloride & $10^{-5}$ & + & + & NA & NA \\
\hline & & $10^{-6}$ & - & - & - & - \\
\hline & Calphostin C & $10^{-6}$ & - & - & - & - \\
\hline & & $10^{-7}$ & - & - & - & - \\
\hline & $\mathrm{H} 7$ & $10^{-4}$ & + & + & NA & NA \\
\hline & & $10^{-5}$ & - & - & - & - \\
\hline \multirow[t]{4}{*}{ Cytoskeletal perturbation } & Cytochalasin D & $10^{-5}$ & - & - & - & - \\
\hline & & $10^{-6}$ & - & - & + & + \\
\hline & & $10^{-7}$ & - & - & + & + \\
\hline & & $10^{-8}$ & - & - & - & - \\
\hline Protein kinase $\mathrm{C}$ activation & PMA & $10^{-6}$ & - & - & + & + \\
\hline \multirow{8}{*}{ Protein serine/threonine phosphatase inhibition } & Okadaic acid & $10^{-7}$ & + & + & NA & NA \\
\hline & & $10^{-8}$ & - & - & - & - \\
\hline & & $10^{-10}$ & - & - & - & - \\
\hline & Calyculin A & $10^{-7}$ & + & + & NA & NA \\
\hline & & $10^{-8}$ & + & + & NA & NA \\
\hline & & $10^{-9}$ & - & - & - & - \\
\hline & Microcystin LR & $10^{-6}$ & + & + & NA & NA \\
\hline & & $10^{-7}$ & - & - & - & - \\
\hline \multirow[t]{3}{*}{ Protein tyrosine phosphatase inhibition } & Sodium metavanadate & $10^{-4}$ & - & - & + & + \\
\hline & & $10^{-5}$ & - & - & - & + \\
\hline & & $10^{-6}$ & - & - & - & - \\
\hline \multirow[t]{4}{*}{ Tyrosine kinase inhibition } & Herbimycin A & $10^{-6}$ & - & - & - & - \\
\hline & Genistein & $10^{-4}$ & - & - & - & + \\
\hline & & $10^{-5}$ & - & - & - & - \\
\hline & & $10^{-6}$ & - & - & - & - \\
\hline Phospholipase C inhibition & U73122 & $10^{-5}$ & - & - & - & - \\
\hline Cyclooxygenase inhibition & Indomethacin & $10^{-6}$ & - & - & - & - \\
\hline Intracellular calcium storage mobilization & Thapsigargin & $10^{-7}$ & - & - & - & - \\
\hline
\end{tabular}

-, no effect; +, an effect on PTH/PTHrP receptor mRNA expression.

NA represents not applicable due to loss of cell attachment.

of increased PTH/PTHrP receptor expression in osteoblasts cultured on type I collagen, together with reports indicating that $\mathrm{PTH} / \mathrm{PTHrP}$ receptor expression is increased as a function of osteoblast maturity (Suda et al. 1995, Bos et al. 1996), led us to examine the expression of other osteoblast-associated gene products. We found that the expression of ALP and OP mRNA was also increased in cells cultured on type I collagen. Although UMR106-06 cells are considered to represent relatively differentiated osteoblasts, enhanced expression of these gene products in cells acutely exposed to exogenous type I collagen is consistent with the need for cellular interaction with collagen for full expression of this phenotype. RA treatment, which induces differentiation of phenotypically preosteoblastic cells (Choong et al. 1993), had opposing effects on ALP and OP mRNA, decreasing the mRNA expression of ALP and increasing the expression of OP mRNA in cells on both substrates, consistent with previous findings with UMR106-06 cells on plastic (Zhou et al. 1991). Downregulation of ALP mRNA expression by RA and collagen was similar to that of the PTH/PTHrP receptor (Celic et al. 1996), with increased expression in cells cultured on type I collagen, compared with cells on plastic, and decreased expression on both substrates with RA treatment. OP, which, according to several models of osteoblast differentiation (Owen et al. 1990) is expressed later than ALP, differed in its response to RA treatment. RA increased the mRNA level on plastic and synergized with the effect of collagen. These results highlight the need to consider the role of physiological ECM substrates in examining cellular responses to soluble factors. 


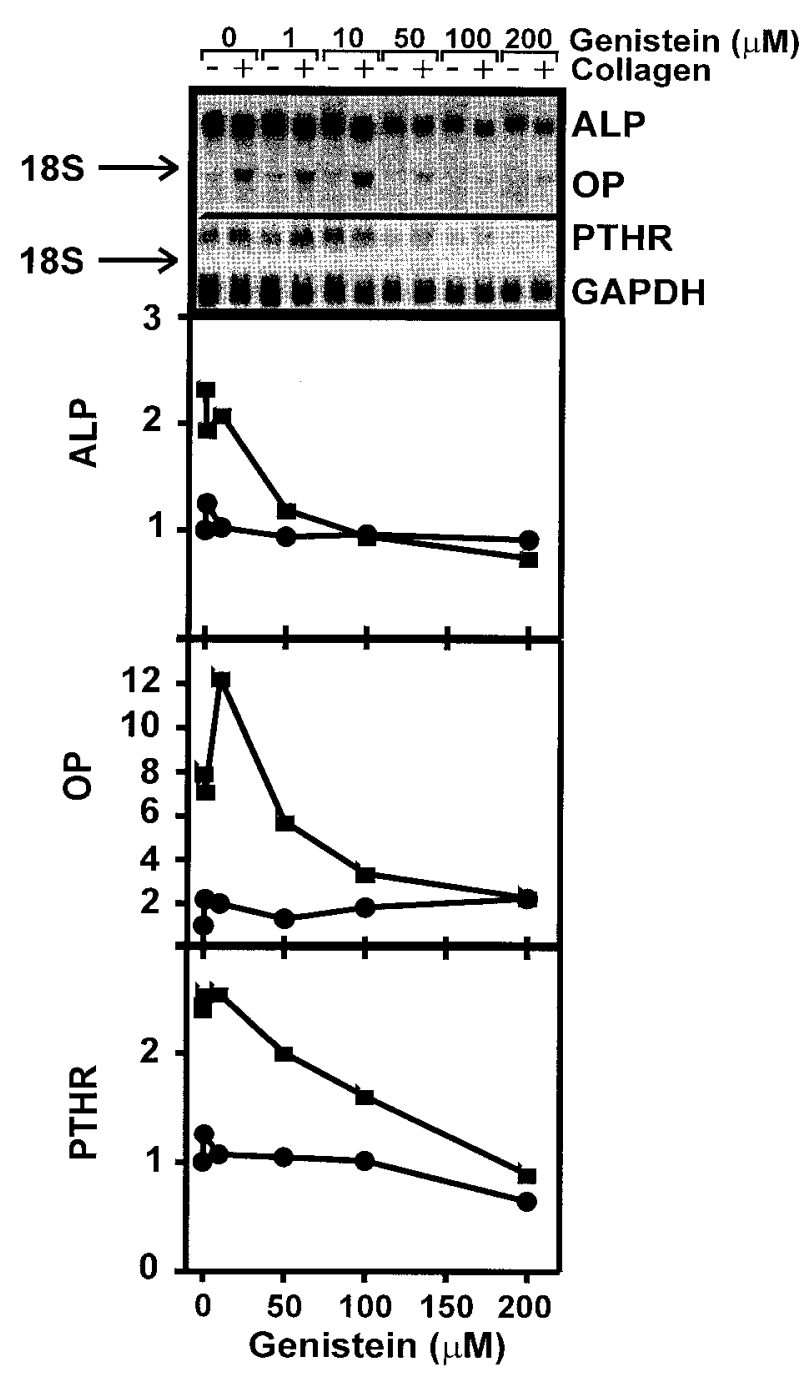

Figure 8 Effect of genistein treatment of UMR106-06 cells cultured on type I collagen or plastic. The cells were plated onto plastic (O) or collagen ( $)$ and incubated in the presence $(+)$ or absence $(-)$ of the indicated concentrations of genistein for $24 \mathrm{~h}$ prior to extraction of total RNA and analysis by Northern blot. Shown is a representative Northern blot with signals corresponding to mRNA for ALP, OP, PTH/PTHrP receptor (PTHR) and the housekeeping gene used for normalization, GAPDH. Quantification of these signals was by phosphorimager analysis and results are expressed as the ratio of ALP, OP or PTHR mRNA levels to GAPDH mRNA levels, where the result for untreated cells on plastic was given the value of 1 . This experiment is representative of two similar experiments.

Current data suggest that cell attachment to collagen can be mediated by cell binding to several sites in the molecule. UMR106-06 cell adhesion to plastic or collagen did not appear to involve an RGD site, given the lack of effect of the GRGDTP peptide in interfering with cell attachment or collagen-mediated effects on mRNA expression in this system. The DGEA motif has been claimed to be the recognition sequence for $\alpha_{2} \beta_{1}$ integrin (Staatz et al. 1991), and has been used to block collagenmediated maturation of MC3T3-E1 osteoblast-like cells (Takeuchi et al. 1996). The experiments described here showed that the DGEA cell-binding domain may be involved, although the results were not entirely unambiguous. In addition, since KDGE also reduced the difference in PTH/PTHrP receptor and ALP mRNA expression between the substrates, this peptide may not be an appropriate negative control in the UMR106-06 cell system, as it is in others (Staatz et al. 1991). The results with respect to a role for the DGEA-containing site as a domain mediating the collagen-induced effects on ALP and $\mathrm{PTH} / \mathrm{PTHrP}$ receptor mRNA expression are thus perhaps supportive of a recent report, in abstract, which suggests that DGEA may have direct actions on cells (McCann et al. 1996).

In order to further investigate the specificity of the collagen effect in UMR106-06 cells for this substrate, we examined the response of cells to chemically modified collagen. Glycation of long-lived macromolecules such as collagen, by reactive sugar moieties, is thought to perturb the interactions of these matrix molecules with their specific cellular receptors (Haitoglou et al. 1992). When primary osteoblasts were cultured on AGE collagen, there was decreased expression of markers associated with differentiation status, such as ALP activity and osteocalcin secretion as well as decreased bone nodule formation, when compared with culture on unmodified collagen (Katayama et al. 1996). In the present studies, AGE collagen decreased the collagen-mediated enhancement of the PTH/PTHrP receptor mRNA and OP mRNA, dose-dependently with respect to the AGE content. In contrast, ALP mRNA expression appeared to be regulated differently from the other two mRNA species and was resistant to the effects of AGE modification of collagen at all levels of glycation.

Cell binding to ECM molecules elicits a number of intracellular signalling events, although the complete signal transduction mechanisms leading to ECM-induced cell changes are not known in any cell type. We have obtained evidence that tyrosine phosphorylation is involved in the collagen-induced events seen in UMR106-06 cells. Inhibition of tyrosine phosphatase activity or of a tyrosine kinase(s), sensitive to inhibition by genistein but not herbimycin A, inhibited the collagenmediated increase in expression of the various mRNA species. Interpretation of these results is difficult and much more work will be required to delineate the intracellular signalling pathways to which these phosphorylation events belong. The differential regulation of tyrosine kinase activity by the inhibitors genistein and herbimycin A has been shown in other systems (Langholz et al. 1995) and may relate to their differing modes of action; genistein competes at the ATP-binding site (Akiyama et al. 1987) and thus has a broad range of action, whereas herbimycin 
A binds to src-homology motifs (Fukazawa et al. 1991), which confers a narrower range of action. However, it is important to note here that, while genistein is considered a selective inhibitor of tyrosine kinases, other activities of this compound have been reported (Markovits et al. 1989, Nakashima et al. 1991, Kniss et al. 1996).

Thus the results presented here further support the concept that the ECM of bone is important in the differentiation and function of osteoblasts. Mechanistically, the substrate-induced events in these cells appear to be mediated by direct interaction between cells and the collagen molecule and may involve tyrosine phosphorylation. These data will provide a starting point in identifying signalling pathways and phosphorylation substrates involved in the collagen-mediated regulation of gene expression in osteoblasts.

\section{Acknowledgements}

This work was supported by a programme grant from the National Health and Medical Research Council of Australia, of which D M F was a Senior Research Fellow. We are grateful to Dr Patrick Sexton for assistance with analysis of binding data, Dr Tina Soulis for immunohistochemical analysis of RAGE, and Athena Kladis and Anthony Valentijn for assistance with radioactive labelling of the PTH/PTHrP receptor peptide.

\section{References}

Abou-Samra AB, Juppner H, Force T, Freeman MW, Kong XF, Schipani E, Richards J, Bonventre JV, Potts JT Jr, Kronberg HM \& Segre GV 1992 Expression cloning of a common receptor for parathyroid hormone and parathyroid hormone-related peptide from rat osteoblast-like cells: a single receptor stimulates intracellular accumulation of both cAMP and inositol trisphosphates and increases intracellular free calcium. Proceedings of the National Academy of Sciences of the USA 89 2732-2736.

Adams JC \& Watt FM 1993 Regulation of development and differentiation by the extracellular matrix. Development 177 1183-1198.

Akiyama T, Ishida J, Nakagawa S, Ogawara H, Watanabe S, Itoh N, Shibuya M \& Fukami Y 1987 Genistein, a specific inhibitor of tyrosine-specific protein kinases. Journal of Biological Chemistry 262 5592-5595

Andrianarivo AG, Robinson JA, Mann KG \& Tracy RP 1992 Growth on type I collagen promotes expression of the osteoblastic phenotype in human osteosarcoma MG-63 cells. Journal of Cellular Physiology 153 256-265

Arcari P, Martinelli R \& Salvatore F 1984 The complete sequence of a full length cDNA for human liver glyceraldehyde-3-phosphate dehydrogenase: evidence for multiple mRNA species. Nucleic Acids Research 12 9179-9189.

Blum JL, Zeigler ME \& Wicha MS 1987 Regulation of rat mammary gene expression by extracellular matrix components. Experimental Cell Research 173 322-340.

Bos MP, Van Der Meer JM, Feyen JHM \& Herrmann-Erlee MPM 1996 Expression of the parathyroid hormone receptor and correlation with other osteoblastic parameters in fetal rat osteoblasts. Calcified Tissue International 58 95-100.
Celic S, Chilco PJ, Zajac JD, Martin TJ \& Findlay DM 1996 A type I collagen substrate increases PTH/PTHrP receptor mRNA expression and suppresses PTHrP mRNA expression in UMR106-06 osteoblast-like cells. Journal of Endocrinology 150 299-308

Chomczynski P \& Sacchi N 1987 Single-step method of RNA isolation by acid guanidinium thiocyanate-phenol-chloroform extraction. Analytical Biochemistry 162 156-159.

Choong PFM, Martin TJ \& Ng KW 1993 Effects of ascorbic acid, calcitriol, and retinoic acid on the differentiation of preosteoblasts. Journal of Orthopaedic Research 11 638-647.

Eyer DR 1980 Collagen: molecular diversity in the body's protein scaffold. Science 207 1315-1322.

Forrest SM, Ng KW, Findlay DM, Michelangeli VP, Livesey SA, Partridge NC, Zajac JD \& Martin TJ 1985 Characterisation of an osteoblast-like clonal cell line which responds to both parathyroid hormone and calcitonin. Calcified Tissue International 37 $51-56$.

Fukazawa H, Li PM, Yamamoto C, Murakami Y, Mizuno S \& Uehara Y 1991 Specific inhibition of cytoplasmic protein tyrosine kinases by herbimycin A in vitro. Biochemical Pharmacology 42 1661-1671.

Goldman ME, Chorev M, Reagan JE, Nutt RF, Levy JJ \& Rosenblatt M 1988 Evaluation of novel parathyroid hormone analogs using a bovine renal membrane receptor binding assay. Endocrinology 123 1468-1475.

Haitoglou CS, Tsilibary EC, Brownlee M \& Charonis AS 1992 Altered cellular interactions between endothelial cells and nonenzymatically glucosylated laminin/type IV collagen. Journal of Biological Chemistry 267 12404-12407.

Hynes RO 1992 Integrins: versatility, modulation, and signaling in cell adhesion. Cell 69 11-25.

Katayama Y, Akatsu T, Yamamoto M, Kugai N \& Nagata N 1996 Role of nonenzymatic glycosylation of type I collagen in diabetic osteopenia. Journal of Bone and Mineral Research 11 931-937.

Kniss DA, Zimmerman PD, Su H-C \& Fertel RH 1996 Genistein suppresses EGF-induced prostaglandin biosynthesis by a mechanism independent of EGF receptor tyrosine kinase inhibition. Prostaglandins 51 87-105.

Kornberg LJ, Earp HS, Turner CE, Prockop C \& Juliano RL 1991 Signal transduction by integrins: increased protein tyrosine phosphorylation caused by clustering of $\beta 1$ integrins. Proceedings of the National Academy of Sciences of the USA 88 8392-8396.

Langholz O, Rockel D, Mauch C, Kozlowska E, Bank I, Krieg T \& Eckes B 1995 Collagen and collagenase gene expression in three-dimensional collagen lattices are differentially regulated by $\alpha 1 \beta 1$ and $\alpha 2 \beta 1$ integrins. Journal of Cellular Biology 131 1903-1915.

Lynch MP, Stein JL, Stein GS \& Lian JB 1995 The influence of type I collagen on the development and maintenance of the osteoblast phenotype in primary and passaged rat calvarial osteoblasts: modification of expression of genes supporting cell growth, adhesion, and extracellular matrix mineralization. Experimental Cell Research 216 35-45.

McCann T, Mason WT \& McDonald F 1996 DGEA, a collagen peptide motif, mobilizes internal $\mathrm{Ca}^{2+}$ stores independently of $\alpha_{2} \beta_{1}$ integrin in human osteoblast-like SaOS-2 cells. Molecular Biology of the Cell 7 590a.

McCauley LK, Koh AJ, Beecher CA, Cui Y, Decker JD \& Franceschi RT 1995 Effects of differentiation and transforming growth factor $\beta 1$ on PTH/PTHrP receptor mRNA levels in MC3T3-E1 cells. Journal of Bone and Mineral Research 10 1243-1255.

McPherson GA 1985 Analysis of radioligand binding experiments: a collection of computer programs for the IBM PC. Journal of Pharmacological Methods 14 213-228.

Markovits J, Linassier C, Fosse P, Couprie J, Pierre J, JacqueminSablon A, Saucier J-M, Le Pecq J-B \& Larsen AK 1989 Inhibitory effects of the tyrosine kinase inhibitor genistein on mammalian DNA topoisomerase II. Cancer Research 49 5111-5117. 
Munson PJ \& Rodbard D 1980 Ligand: a versatile computerized approach for characterization of ligand-binding systems. Analytical Biochemistry 107 220-239.

Nakashima S, Koike T \& Nozawa Y 1991 Genistein, a protein tyrosine kinase inhibitor, inhibits thromboxane A2-mediated human platelet responses. Molecular Pharmacology 39 475-480.

Noda M \& Rodan GA 1987 Type $\beta$ transforming growth factor (TGF $\beta$ ) regulation of alkaline phosphatase expression and other phenotype-related mRNA in osteoblastic rat osteosarcoma cells. Journal of Cellular Physiology 133 426-437.

Owen TA, Aronow M, Shalhoub V, Barone LM, Wilming L, Tassinari MS, Pockwinse S, Lian JB \& Stein GS 1990 Progressive development of the rat osteoblast phenotype in vitro: reciprocal relationships in expression of genes associated with osteoblast proliferation and differentiation during formation of the bone extracellular matrix. Journal of Cellular Physiology 143 $420-430$.

Sambrook J, Fritsch EF \& Maniatis T 1989 Molecular Cloning: a Laboratory Manual. New York: Cold Spring Harbor Laboratory Press.

Schwartz MA, Schaller MD \& Ginsberg MH 1995 Integrins: emerging paradigms of signal transduction. Annual Review of Cell Developmental Biology 11 549-599.

Shankar G, Davison I, Helfrich MH, Mason WT \& Horton MA 1993 Integrin receptor-mediated mobilisation of intranuclear calcium in rat osteoclasts. Journal of Cell Science 105 61-68.

Staatz WD, Fok KF, Zutter MM, Adams SP, Rodriguez BA \& Santoro SA 1991 Identification of a tetrapeptide recognition sequence for the $\alpha 2 \beta 1$ integrin in collagen. Journal of Biological Chemistry 266 7363-7367.

Suda N, Kuroda T, Gillespie MT, Zhou H, Ho PWM, Hards DK, Martin TJ \& Moseley JM 1995 Differential expression of parathyroid hormone-related protein and its receptor in rat calvariae. Journal of Bone and Mineral Research 10 S172.

Takeuchi Y, Nakayama K \& Matsumoto T 1996 Differentiation and cell surface expression of transforming growth factor- $\beta$ receptors are regulated by interaction with matrix collagen in murine osteoblastic cells. Journal of Biological Chemistry 271 3938-3944.

Traianedes K, Ng KW, Martin TJ \& Findlay DM 1993 Cell substratum modulates responses of preosteoblasts to retinoic acid. Journal of Cellular Physiology 157 243-252.

Turner CE \& Burridge K 1991 Transmembrane molecular assemblies in cell-extracellular matrix interactions. Current Opinion in Cell Biology 3 849-853.

Yoon K, Buenaga R \& Rodan G 1987 Tissue specificity and developmental expression of rat osteopontin. Biochemical and Biophysical Research Communications 148 1129-1136.

Zhou H, Hammonds GRJ, Findlay DM, Fuller PJ, Martin TJ \& Ng KW 1991 Retinoic acid modulation of mRNA levels in malignant, nontransformed and immortalized osteoblasts. Journal of Bone and Mineral Research 6 767-777.

Received 19 December 1997

Revised manuscript received 1 April 1998

Accepted 5 May 1998 